\title{
Article/Artigo
}

\section{Autochthonous visceral leishmaniasis in Brasília, Federal District, Brazil}

\author{
Leishmaniose visceral autóctone em Brasília, Distrito Federal, Brasil
}

\author{
César Omar Carranza-Tamayo ${ }^{1}$, Maria do Socorro Laurentino de Carvalho' ${ }^{2}$, Angelika Bredt ${ }^{2}$, Maria Isabel \\ Rao Bofil ${ }^{2}$, Rodrigo Menna Barreto Rodrigues ${ }^{2}$, Ailton Domício da Silva ${ }^{3}$, Sandra Maria Felipe Coelho Cortez ${ }^{3}$ \\ and Gustavo Adolfo Sierra Romero ${ }^{1}$
}

\begin{abstract}
Introduction: Visceral leishmaniasis is a public health threat in Brazil considering the high lethality rates and increasing geographical dispersion to large urban conglomerates over the past 25 years. This study aimed to confirm suspected autochthonous cases of visceral leishmaniasis reported from 2005 to 2009 among individuals living in Brasilia, Federal District. Methods: A retrospective review of the surveillance data obtained on a regular basis and clinical records of the reported cases were performed in 2009. Results: Data from entomological and canine surveys revealed the presence of both Lutzomyia longipalpis and positive serology for Leishmania in dogs within 19 of the 21 neighborhoods where human cases occurred since 2005 . The review of surveillance data and medical records, together with the entomological and canine survey data, permitted confirmation of 21 autochthonous human cases in the Federal District. The disease predominantly affected children $(12 / 21)$ and those from the Sobradinho region $(16 / 21)$; the typical presentation of fever, hepatosplenomegaly and pancytopenia was observed in $67 \%$ of cases. Three deaths occurred during the study period. Leishmania (Leishmania) chagasi was successfully isolated from one human case and twelve canine cases. Conclusions: Visceral leishmaniasis should be considered endemic in Brasilia based on the documented epidemiological behavior herein described and the confirmed autochthony of human cases.

Key-words: Visceral leishmaniasis. Autochthony. Leishmania chagasi. Leishmania infantum. Lutzomyia longipalpis.
\end{abstract}

\section{RESUMO}

Introdução: A leishmaniose visceral é uma ameaça para a saúde pública no Brasil, considerando a elevada taxa de letalidade e a sua dispersão geográfica para grandes conglomerados urbanos durante os últimos 25 anos. Este trabalho teve como objetivo confirmar a suspeita de autoctonia de casos de leishmaniose visceral notificados de 2005 até 2009 em moradores de Brasília, Distrito Federal. Métodos: Foi realizado em 2009 um estudo retrospectivo dos dados da vigilância obtidos na rotina e dos registros clínicos dos casos humanos notificados. Resultados: Os dados dos inquéritos canino e entomológico revelaram a presença de Lutzomyia longipalpis e de cães com sorologia positiva para Leishmania na vizinhança onde ocorreram 19 dos 21 casos humanos desde 2005. A revisão das fichas de notificação e prontuários dos pacientes, em conjunto com os dados dos inquéritos canino e entomológico permitiram a comprovação da autoctonia de 21 casos humanos no Distrito Federal. A doença afetou predominantemente crianças $(12 / 21)$, da região de Sobradinho (16/21), com quadro típico de febre, hepatoesplenomegalia e pancitopenia em $67 \%$ dos casos. Houve três óbitos no período. Houve sucesso no isolamento de Leishmania (Leishmania) chagasi de um caso humano e de doze casos caninos. Conclusões: A leishmaniose visceral deve ser considerada endêmica em Brasília, considerando o comportamento epidemiológico aqui descrito e a confirmação da autoctonia dos casos humanos.

Palavras-chaves: Leishmaniose visceral. Autoctonia. Leishmania chagasi. Leishmania infantum. Lutzomyia longipalpis.

1. Tropical Medicine Unit, University of Brasilia, Brasília, DF, Brazil. 2. Enviromental Surveillance Directory, Health State Secretariat, Brasilia, DF, Brazil. 3. Endemic and Emergent Diseases Control Unit, Health State Secretariat, Brasilia, DF, Brazil.

Address to: Dr. Gustavo Adolfo Sierra Romero. NMT/UnB. Caixa Postal 04517, Campus Universitário Darcy Ribeiro, 70904-970 Brasília, DF, Brasil.

Tel: 5561 3273-5008; Fax: 5561 3273-2811

e-mail: gromero@unb.br

Received in 05/04/2010

Accepted in 07/05/2010

\section{INTRODUCTION}

Visceral leishmaniasis (VL) is a zoonotic disease characterized by fever, weight loss, hepatosplenomegaly and cytopenias. In Latin America, there has been an increase in the number of cases with wide geographic distribution and efforts to achieve the recommended control measures for the disease have been hindered by several major challenges ${ }^{1}$. While VL has been reported in all Brazilian regions, the southern region has seen only sporadic cases ${ }^{2,3}$. In the past, VL was considered a rural zoonosis, but today, it affects medium and large urban centers, a phenomenon known as VL urbanization ${ }^{4}$. The first urban epidemic in Brazil occurred 25 years ago in the city of Teresina, State of Piaui $^{5}$, and since then, several outbreaks have been reported in the periphery of other cities, such as São Luiz, State of Maranhão; Belo Horizonte, State of Minas Gerais; Rio de Janeiro, State of Rio de Janeiro; Campo Grande, State of Mato Grosso do Sul; and Palmas, State of Tocantins ${ }^{6-9}$. According to the Ministry of Health, Brasília has reported VL cases since 2000. However, in the University Hospital of Brasília, we were able to find records of the disease dating from 1983 (Castro $\mathrm{CN}$ and Carranza-Tamayo CO: unpublished data); all of these patients were from neighboring states, mainly Bahia, Minas Gerais and Goias. The Federal District is surrounded by municipalities with reports of autochthonous transmission of $\mathrm{VL}$ and all patients reported with the disease before 2005 came from municipalities outside the Federal District. In July 2005, the first VL case suspected of being autochthonous was diagnosed in Brasilia.

This study was a collaborative effort between the Tropical Medicine Unit at the University of Brasilia (NMT-UnB), the Enviromental Surveillance Directory (DIVAL) and the Endemic and Emergent Diseases Control Unit (NEDTE) of the Health State Secretariat of the Federal District (SESDF), designed to assess both the autochthony of human VL cases reported to the national surveillance system from 2005 to 2009 and to describe the clinical and epidemiological features of these cases. 


\section{METHODS}

\section{Study area}

The Sobradinho region is located north of the central area of Brasilia and since 2004, it has been divided into Sobradinho I and II. Sobradinho II's rural areas (called Fercal) have been identified as the place where the first cases of VL of autochthonous transmission originated. Fercal is an area initially formed around a cement factory from which the area takes its name. Mining for the cement factory uses the so-called limestone seasonal forest for extracting limestone as raw material for the manufacture of cement. Human settlements composed of people who came to work at the cement factory formed the communities that are now collectively known as the Fercal. The region is characterized by limestone and significant areas are covered by cerrado, semideciduous forest and dense savannah. The presence of humans in this region has led to the degradation of many areas. Around the cement factories there are thirteen communities, four of them with typical rural characteristics (Boa Vista, Catingueiro, Córrego do Ouro and Ribeirão, Pedreira); i.e., consisting of scattered farms and ranches with few inhabitants in each one. Other communities are composed of clusters of houses in the middle of original, forested savannah. Of the nine other communities, five have reported cases of VL (Bananal, Curvas, Engenho Velho, Fercal Leste and Queima Lençol).

\section{Human cases}

All cases of VL in the Federal District during the study period were reviewed. Autochthony was evaluated taking into consideration the following criteria: living in the Federal District for at least six months before the diagnosis of VL; presence of VL arthropod vectors inside the home and/or neighborhood; presence of VL-seropositive dogs at the home or in the neighborhood; and lack of exposure to other areas of risk for transmission of VL outside the Federal District. The evaluation began with the revision of surveillance records obtained from the National Disease Notification Information System (Sistema Nacional de Agravos de Notificação, SINAN) at the NEDTE and then proceeded with the review of medical records of the selected patients, in order to register personal, clinical and epidemiological features of their case presentations.

\section{Entomological survey}

The records of sandfly capture activities from routine entomological surveillance conducted by DIVAL personnel during the study period in communities with reported human VL cases were reviewed. The capture of sandflies was conducted using CDC traps placed for 3-4 consecutive nights in households, dwellings and receptive sandfly areas, such as kennels and poultry houses. The same routine was conducted in randomly selected areas in the communities where suspected cases of VL occurred and in neighboring communities to the study area. Samples were collected in four different time frames after the notification of suspected VL cases. Routine sandfly captures were conducted from July 2004 to September 2005, January 2006 to May 2007, May to November 2008 and throughout 2009. Outside these periods, captures were performed only in communities with suspected cases of autochthonous VL transmission.

\section{Canine survey}

During the study period, serum samples were collected from all dogs whose owners agreed to the procedure in the communities with suspected cases of human VL and in neighboring communities. The samples were assessed by the indirect immunofluorescence antibody test (IFAT) using a positivity cut-off of $1: 80^{10}$. Seropositive dogs were collected and euthanized according to the protocol outlined by the Brazilian VL control program ${ }^{10}$. Bone marrow, liver, lymph nodes, spleen and skin samples were taken from 162 euthanized dogs and cultured in a semisolid medium in the Leishmaniasis Laboratory of the NMT-UnB.

\section{Ethical}

This study was conducted in a retrospective manner and the institutional authorization to access to the surveillance and clinical records was properly obtained. Thus, approval by the institution's ethics committee was not required, since no potential risks were identified for the human subjects. The authors were committed to maintaining the personal data of human cases undisclosed.

\section{RESULTS}

\section{Human cases}

Up to December 2009, 21 cases of VL were reported that met the autochthony criteria. The distribution of cases by year and place of residence is presented in Table 1. VL tended to aggregate in the second half of each year (July - December), which corresponds mainly to the dry season in Brasília. A total of 15 (71\%) cases were reported during this season. The disease affected 12 children and nine adults whose ages ranged from nine months to 65 yearsold (median age 9 years-old). One patient from Vila Rabelo I (in Sobradinho II) had two clinical relapses (first diagnosis in January 2008, first relapse in December 2008 and a second relapse episode in July 2009). The male ratio was $1.1(11 / 10)$. Most of the patients $(17 / 21.8 \%)$ came from the Sobradinho region. Two patients had an immunosuppressive condition at the time of diagnosis: one of them was seropositive for HIV and the other one was on corticoid therapy for a rheumatologic disease. The typical presentation of fever with splenomegaly and pancytopenia was observed in 14 (67\%) cases. Clinical and laboratory features are described in Figure 1.

Seven patients required a blood transfusion and nine patients met the criteria for severity ${ }^{11}$, which was characterized by jaundice and/or bleeding. Of these, five were treated with amphotericin B and four

TABLE 1 - Distribution of autochthonous cases of visceral leishmaniasis in Brasília, Federal District, according to year of diagnosis, residence and epidemiological features. 2005-2009.

\begin{tabular}{|c|c|c|c|c|c|c|}
\hline Year & Cases & $\begin{array}{c}\text { Administrative } \\
\text { region }\end{array}$ & $\begin{array}{c}\text { Entomological } \\
\text { survey }^{*}\end{array}$ & $\begin{array}{c}\text { Canine } \\
\text { survey }^{* *}\end{array}$ & $\begin{array}{l}\text { Child } \\
\text { adults }\end{array}$ & Deaths \\
\hline 2005 & 2 & Sobradinho & positive & positive & $1 / 1$ & - \\
\hline \multirow{3}{*}{2006} & 6 & Brazlândia (01) & negative & negative & $4 / 2$ & 2 \\
\hline & & Ceilândia （01） & negative & negative & & \\
\hline & & Sobradinho (04) & positive & positive & & \\
\hline 2007 & 3 & Sobradinho & positive & positive & $2 / 1$ & - \\
\hline \multirow[t]{2}{*}{2008} & 5 & Lago Norte (01) & positive & positive & $2 / 3$ & - \\
\hline & & Sobradinho (04) & positive & positive & & \\
\hline \multirow[t]{2}{*}{2009} & 5 & Lago Norte (01) & positive & positive & $3 / 2$ & 1 \\
\hline & & Sobradinho (04) & positive & positive & & \\
\hline
\end{tabular}

*Positive corresponds to presence of Lutzomyia longipalpis at the home or within the neighborhood of human VL cases.

*** Positive corresponds to presence of Leishmania seropositive dogs (reagent immunofluorescence reaction $\geq 1: 80$ ) at the home or within the neighborhood of human VL cases. 


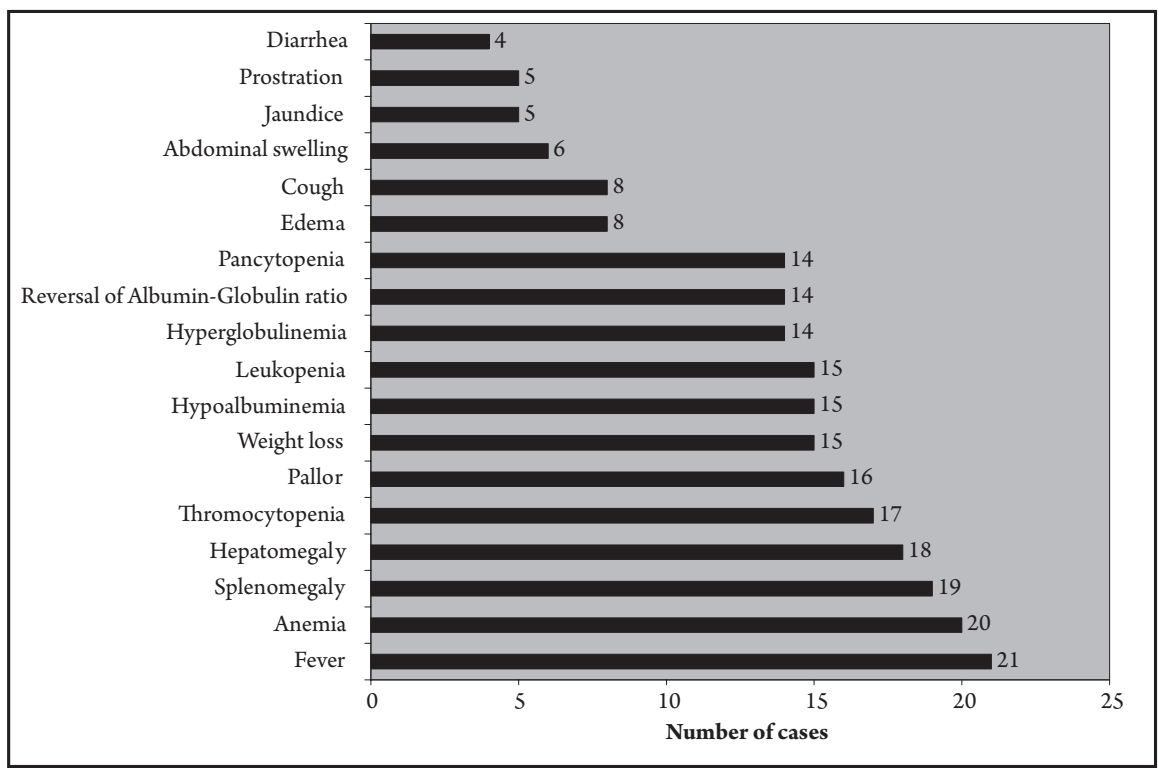

FIGURE 1 - Clinical and laboratory features of autochthonous visceral leishmaniasis cases in Brasilia, Federal District, 2005-2009.

were treated with pentavalent antimony. Fourteen patients presented concomitant infections: eight cases of pneumonia, four cases of sepsis with unidentified source, one otitis media and one sinusitis.

There were three fatal cases, all of which occurred in individuals with bleeding episodes, and the first two deaths occurred in 2006. The first case was a six year-old malnourished child who in addition to a typical VL presentation, also had gingival bleeding, jaundice and sepsis. In the same year, a nine month-old infant died from VL, which was confirmed by positive bone marrow smears and serology. In this case, it was not possible to confirm the infection in the mother, whose serology test was negative. The infant had complications, including ecchymosis and pneumonia, and died of septic shock and multiple organ failure. The third death occurred in 2009, when a 65 year-old woman underwent therapy for a suspected rheumatic disease. This patient presented in the final stage with ulcerated lesions on the lower lip and buttocks and the skin biopsy showed amastigotes of Leishmania. She later developed pneumonia, poor general condition, microscopic hematuria and pancytopenia. Finally, she was diagnosed through the identification of Leishmania in bone marrow smears.

Bone marrow smears were positive in 11 cases. One case was diagnosed by a culture of Leishmania and by positive kDNA polymerase chain reaction (PCR) in a bone marrow sample. This isolate was identified by enzyme electrophoresis as Leishmania chagasi ${ }^{12}$. Seven cases were confirmed solely by serology. With the availability of the rapid test Kalazar Detect ${ }^{\circledR}$ (INBios International, Inc.) ${ }^{13}$ in 2008, one patient's diagnosis was only confirmed by this method. One case underwent a therapeutic test with Glucantime ${ }^{\circledR}$ (Aventis, São Paulo, Brazil) and showed improvement after treatment. Seventeen (81\%) patients were treated with intravenous Glucantime ${ }^{\circledR}$ and the remaining patients were treated with amphotericin $\mathrm{B}$. The duration of treatment with antimonials ranged from 13 to 30 days. Fifteen patients were treated with the conventional dose of $20 \mathrm{mg} / \mathrm{kg} /$ day of pentavalent antimonial and two patients used a dose of $15 \mathrm{mg} / \mathrm{kg} /$ day. The only reported reaction to the antimonial therapy was an episode of cardiac arrhythmia observed in an eight year-old child. Among those treated with amphotericin B, three developed uremia, which was resolved by dose adjustment and vigorous hydration. The patient with HIV/VL coinfection received liposomal amphotericin B. Eighteen cases were considered cured at the end of treatment and three died. The patient who relapsed was treated with two pentavalent antimony courses of 28 days each and amphotericin B ( $1 \mathrm{~g})$ for the second relapse; the patient was considered cured after the last therapy.

\section{Canine survey}

The serological evaluation of dogs residing in areas with human VL cases showed the presence of seropositive dogs in the regions of Lago Norte (Lago Norte and Varjão) and Sobradinho (Alvorada II, Serra Azul, Uberaba, Fercal, Lago Oeste and Vila Rabelo I and II). In the Lago Norte and Lago Oeste regions, some dog owners paid for other confirmatory tests from private veterinary services and some of them demonstrated positivity in PCR tests for Leishmania. These animals were euthanized or died from the disease. Among the dogs euthanized from the Sobradinho region ( $\mathrm{n}=162), 15 \%$ of Leishmania cultures from bone marrow, liver, lymph nodes, spleen and/or skin were positive. Twelve of these isolates were identified as L. chagasi by enzyme electrophoresis ${ }^{12,14}$. Serological canine surveys conducted in the Brazlândia and Ceilândia regions (both in 2006) showed no positive reactions.

\section{Entomological survey}

The capture of sandflies showed the presence of Lutzomyia longipalpis in residential areas where 19 human cases occurred. The surveys conducted in Brazlândia and Ceilândia cases did not demonstrate the presence of the arthropod vector in 2006 . These two communities were reassessed in 2008 and 2009 and remained without evidence of $\mathrm{Lu}$. longipalpis. Other areas without reported human VL cases showed the presence of this vector, including: the communities of Quebrada dos Neres (São Sebastião) in 2005; Núcleo rural Cava de Baixo (São Sebastião) and Ponte Alta Norte (Gama) between 2006 and 2007; the rural communities of Capão Seco and Capão da Onça (Paranoá) in 2008; and finally, Jardim Botânico and Lago Sul in 2009. These results demonstrated the wide distribution of Lu. longipalpis in Federal District communities.

\section{DISCUSSION}

The movement of people into wilderness areas leads to increased risk of encounters with infective agents like Leishmania due to the convergence of people, vectors and reservoirs. Sandflies are able to feed on people living in homes located close to the original forest; in 
addition, they are even more likely to be a vector when other animal food sources exist, such as dogs or hens ${ }^{15}$.

This research demonstrated the presence of infected dogs and detected arthropod vectors in areas involving cases of human VL. The Fercal region is an area with high population dynamics and where whole families, attracted by the city and local industries, arrive looking for jobs. This migratory phenomenon could have been responsible for VL introduction through the arrival of dogs with the disease that was subsequently transmitted to humans. Prior to notification of the human disease in Brasilia, cases of dogs with VL acquired in the cities of Palmas and Belo Horizonte that migrated along with their owners to the Federal District had be diagnosed and documented (Romero GAS: unpublished data). Indeed, these infected animals may have arrived in Brasília in large numbers from the neighboring States of Goiás, Bahia and Minas Gerais. It is noteworthy that the states of Bahia and Goiás have reported human VL since the $1950 \mathrm{~s}^{16}$.

With the exception of the cases from Brazlândia and Ceilândia, the autochthony of all the human VL cases was supported by positive canine and entomological surveys. The case in Brazlândia was diagnosed by suggestive clinical signs and symptoms and evidence of improvement after specific therapy was observed. In spite of the absence of vectors and infected reservoirs, this case was considered autochthonous because it was impossible to demonstrate relevant exposure outside the Federal District. In the case of the nine monthold infant from Ceilândia, there was no demonstration of canine infection or vector presence at the baby's home or outside it. The mother of this last patient had traveled to an endemic VL area in Tocantins during pregnancy, but it was impossible to demonstrate maternal infection. Since the infant was not exposed outside the Federal District, the case was considered autochthonous. This case could be attributed to congenital transmission of the disease, but we were unable to prove this hypothesis. Meinecke et al. reviewed a number of cases worldwide in 1999, stating that congenital VL appears more often among children from mothers with symptomatic VL during pregnancy; however, it may also present in asymptomatic infections, where positive serology is the only sign of the mother's infection ${ }^{17}$. Some authors have reported the absence of vectors in areas where human cases have occurred, which could be due to the lack of efficiency in the sandfly capture method, the presence of other routes of transmission or different unidentified reservoirs ${ }^{18-20}$.

As a result of this study, it can be concluded that VL has become endemic in Brasília. The human case series reported here demonstrates that the disease behavior is similar to that observed in other localities in Brazil in that it affects mainly children and young people with a clinical presentation of fever associated with spleen and liver enlargement and cytopenias.

The precise magnitude of human infection in the Sobradinho area, the place where most of the reported cases occurred, is unknown. The development of a human survey is required, using serological techniques and the leishmanin skin test to assess this issue.

\section{ACKNOWLEDGMENTS}

The authors would like to thank Dra. Elisa Cupolillo of the Instituto Oswaldo Cruz, FIOCRUZ-RJ for the identification of isolated parasites by enzyme electrophoresis.

\section{CONFLICT OF INTEREST}

The authors declare that there is no conflict of interest.

\section{FINANCIAL SUPPORT}

Conselho Nacional de Desenvolvimento Científico e Tecnológico - Ministério de Ciência e Tecnologia.

\section{REFERENCES}

1. Romero GA, Boelaert M. Control of visceral leishmaniasis in Latin America - a systematic review. PLoS Negl Trop Dis 2010; 4:e584.

2. Ayala MAR, Bergoxc PM, Anunciação EM. Calazar (primeiro caso autóctone no Sudeste do Paraná). J Bras Med 1980; 39:88-89.

3. Cat I, Luz E, Borba AM, Cassilha A, Costa PB, Martins FL. Leishmaniose visceral autóctone no oeste paranaense. Anais Fac Med Univ Fed Paraná 1973/1974; 16/17:27-35.

4. Werneck GL. Forum: geographic spread and urbanization of visceral leishmaniasis in Brazil. Introduction. Cad Saude Publica 2008; 24:2937-2940.

5. Costa CHN, Pereira HF, Araújo MV. Epidemia de leishmaniose visceral no estado do Piauí, Brasil, 1980-1986. Rev Saude Publica 1990; 24:361-372.

6. da Luz ZMP, Pimenta DN, Cabral ALLV, Fiúza VOP, Rabello A. A urbanização das leishmanioses e a baixa resolubilidade diagnóstica em municípios da Região Metropolitana de Belo Horizonte. Rev Soc Bras Med Trop 2001; 34:249-254.

7. Marzochi MCA, Marzochi KBF, Carvalho RW. Visceral leishmaniasis in Rio de Janeiro. Parasitol Today 1994; 10:37-40.

8. Mestre GLC, Fontes CJF. A expansão da epidemia da leishmaniose visceral no Estado de Mato Grosso, 1998-2005. Rev Soc Bras Med Trop 2007; 40:42-48.

9. Silva AR, Viana GMC, Varonil C, Pires B, Nascimento MDSD, Costa JML Leishmaniose visceral (calazar) na Ilha de São Luís, Maranhão, Brasil: evolução e perspectivas. Rev Soc Bras Med Trop 1997; 30:359-368.

10. Ministério da Saúde. Manual de Vigilância e Controle da Leishmaniose visceral $1^{\text {a }}$ ed. Brasília: Ministério da Saúde; 2006.

11. Ministério da Saúde. Leishmaniose visceral grave. Normas e condutas $1^{\text {a }}$ ed. Brasília: Ministério da Saúde; 2006.

12. Cupolillo E, Grimaldi Jr G, Momen H. A general classification of New World Leishmania using numerical zymotaxonomy. Am J Trop Med Hyg 1994; 50:296-311.

13. Sundar S, Maurya R, Singh RK, Bharti K, Chakravarty J, Parekh A, et al. Rapid, noninvasive diagnosis of visceral leishmaniasis in India: comparison of two immunochromatographic strip tests for detection of anti-K39 antibody. J Clin Microbiol 2006; 44:251-253.

14. Carranza-Tamayo CO, Bofill MIR, Massunaga PNT, Rodrigues RMB, de Castro $\mathrm{MB}$, Cupolillo E, et al. Leishmaniose canina no primeiro foco de leishmaniose visceral em Brasília - Distrito Federal. In: Resumos da XXIV Reunião de Pesquisa Aplicada em Doença de Chagas e XII Reunião de Pesquisa Aplicada em Leishmanioses. Rev Soc Bras Med Trop 2008; 41(supl III):307-308.

15. Morrison AC, Ferro C, Morales A, Tesh RB, Wilson ML. Dispersal of the sand fly Lutzomyia longipalpis (Diptera: Psychodidae) at an endemic focus of visceral leishmaniasis in Colombia. J Med Entomol 1994; 30:427-435.

16. Amato Neto V, Hikagi Y. Calazar em clínica especializada, na cidade de São Paulo, Brasil. Rev Saude Publica 1980; 14:254-257.

17. Meinecke CK, Schottelius J, Oskam L, Fleischer B. Congenital transmission of visceral leishmaniasis (Kala Azar) from an asymptomatic mother to her child. Pediatrics 1999; 104:e65.

18. Bejarano EE, Uribe S, Rojas W, Dario Velez I. Phlebotomine sand flies (Diptera Psychodidae) associated with the appearance of urban Leishmaniasis in the city of Sincelejo, Colombia. Mem Inst Oswaldo Cruz 2002; 97: 645-647.

19. de Souza MB, Marzochi MC, de Carvalho RW, Ribeiro PC, Pontes CS, Caetano JM et al. Ausência de Lutzomyia longipalpis em algumas áreas de ocorrência de leishmaniose visceral no Município do Rio de Janeiro. Cad Saude Publica 2003; 19:1882-1885.

20. Mancianti F. Leishmaniosi felina: quale ruolo epidemiologico? Parassitol 2004; 46:203-206 